\title{
The research and practice of the Graded teaching mode of the the public mathematics course in Colleges and Universities
}

\author{
Xin Zhao ${ }^{1, \text { a }}$, Jing Wang ${ }^{1, b}$ \\ ${ }^{1}$ College of Information Technology, Jilin Agricultural University, Changchun 130118, China; \\ ajlndzx@sina.com, b'wangjing2227@sina.com
}

Keyword: Teaching management, The Graded teaching mode, People-oriented, The principle of individualized.

\begin{abstract}
College mathematics course is a compulsory public basic course for any majors and it has a very important significance for the development of college students. In order to enable students to achieve the best learning results, the education department had carried out the teaching management to the whole teaching process according to the rules of teaching, including the management of students, teachers, teaching objectives and teaching plans, and so on. Graded teaching mode, as a direction mode, it is based on the ability of students and professional guidance to grade division, and then through a more appropriate education methods to cultivate. This paper introduces the connotation, development, significance of the grade teaching mode, then point out some problems needing attention in the implementation of it of the public mathematics course, and have carried on a further research and thinking in view of the practice experience of the institute of economic management of Jilin Agricultural University.
\end{abstract}

\section{1 preface}

The Ministry of education put forward the policy of College Students' enrollment expansion in 1999. As a result, there are many poor in the foundations of mathematics students also entered the university and because of China's vast territory and large population, the teaching quality grade of each district is different, all of these lead to the students' own math skills gap is larger ${ }^{[1]}$. Mathematics as a basic course is very important to improve students' thinking ability and the ability to solve the problem, but students of different majors need to master different degrees of mathematical knowledge, the mathematics major and similar professional students not only need to understand the theory and the essence of mathematics but also need to have a strong grasp of mathematical thinking and methods; the science and engineering students who use mathematics as a tool need to have the skill to use mathematics to solve practical problems ${ }^{[2]}$; the literature and history major students only need to understand the meaning of mathematical concept. So it is a suitable and necessary new way to carry out the teaching mode of the public mathematics course.

\section{Concept of Graded Teaching}

The Graded teaching mode is based on the student's own ability and career oriented to carry on the level division, take the student-oriented and the principle of individualized, for different grades of students to take targeted education, and carry on the development of different teaching objectives and teaching plans, make best use of the advantages and bypass the disadvantages ${ }^{[3]}$. It can let each student be able to follow the appropriate rules of learning to tap the potential, training more high-quality innovative talents.

\section{The origin and development of Graded Teaching}

The principle of individualized was first proposed by Confucius more than 2000 years ago and he said that there are individual differences among students, educators must be based on the characteristics of the students to carry out targeted education ${ }^{[4]}$. American educator Brumm also put forward that many students did not get excellent results not because of lack of wisdom but because 
they did not get the appropriate teaching methods in the $1960 \mathrm{~s}^{[5]}$. Higher education department also made propose clearly that all colleges should encourage students to adjust their learning goals and methods according to themself in 2004. In recent years, many universities have adopted the graded teaching mode and achieved good results.

\section{The significance of graded teaching}

\subsection{It is conducive to the development of students' individuality}

The teacher can teach students in accordance with students' aptitude , make different learning objectives and methods for different levels students, students are able to develop their individuality through their own learning methods and content.

\subsection{Enhance students' learning initiative}

Because the teachers' learning objectives more eclectic when the unified teaching, this leads to a lot of students are not willing to follow the rhythm of the teacher and lost the enthusiasm of learning. The implementation of the grade teaching mode let students can study at different levels, greatly boosted the overall enthusiasm of the students to learning.

\subsection{Classroom learning atmosphere becomes more active}

Because the students' learning degree is not very different in the same class, so learning progress is the same, thinking is also relatively similar, and for the teachers' problem, most of the students can answer actively and have a serious thinking.

\subsection{Strengthening teachers' strength}

The implementation of grading teaching, can make the teachers more convenient to prepare lessons, and more convenient for teaching ${ }^{[6]}$. The teacher can according to the student's learning situation to make different teaching objectives and teaching plan, improve students' math achievement, at the same time, the teacher's own ability has been improved.

\section{Problems of Graded Teaching}

\subsection{Level is difficult to divide}

We can not follow the same pattern to divided students into different levels, we should according to the actual situation, grasp the scale and number, stimulate the students' upward mobility by carrying out a reasonable rolling division.

\subsection{It is difficult for teachers to assign}

It is generally believed that good students are more management conveniently than poor students, so many teachers want to teach the good students, and teacher's teaching enthusiasm directly affects the teaching results, therefore, it is difficult to do the teacher's distribution work.

\subsection{Student polarization}

In the course of the implementation of the grading teaching, students are likely to form a two degree of differentiation, good foundation students will have a sense of superiority, and poor students will produce a sense of inferiority complex so that lost enthusiasm for learning.

\subsection{Assessment system is difficult to determine}

At present, the major colleges and universities students' final grades have a direct impact on the assessment of scholarship, because the different levels of class teaching process is also very different, easy to appear in the final assessment of the students think that the situation is not fair.

\subsection{Difficulty in teaching management}

The division of students and teachers, together with the students of the class distribution is more dispersed, teachers and Student cadres are unable to do as well as them would wish. All of these increase the difficulty of the work of the school teaching management department.

\section{The practice course of our school}

In order to implement the principle of individualized instruction, further do a good job of professional personnel training, accelerate the growth of students, and establish a comprehensive 
education situation, Jilin Agricultural University let the college of economics and management as a pilot, grade 2012 students for the theory of probability and mathematical statistics course has been carried on the graded teaching. Through learning from other schools in the implementation of graded teaching mode, the school has carried out the reform and implement.

\subsection{The main process is as follows}

\subsubsection{Propaganda}

Let students and teachers are able to fully understand the school to implement the original intention of grading teaching mode, do not produce negative emotions, and cooperate actively with the work.

\subsubsection{Class division}

Performing a math test in the second weeks of freshman enrollment, divide students into development class and improve class according to the college entrance examination and diagnostic test scores each accounted for $50 \%$ proportions, students can give advice to the academic office if they have objections to make up for the one-sided nature of the unified arrangement. In the first week of the second semester, roll adjustment according to the last semester of the mathematical results and the usual results in class to ensure fairness and to improve the students' upward mobility. 6.1.3 Teacher arrangement

Choose teachers by drawing lots after the class division, in order to embody the idea of people-oriented, teachers can also raise to have a further adjustments if they have any problems.

6.1.4 Arrangement of teaching process and teaching material

Due to the different levels of students, teachers in different classes should develop different teaching goals and plans, select the different contents of the unified teaching materials for teaching, the improve class should reduce the target, difficulty and progress, mainly talk about some basic things, and the development class should be relatively improved.

\subsubsection{Achievement evaluation}

Don't take the same test in the final exam for different classes, exam content has a different focus, then combine the credit system to evaluate, improve class's credit is 0.5 lower than the development class, to ensure the fairness and justice of the final assessment.

\subsection{Result analysis}

In order to compare the grading teaching achievements, mathematics teacher of Jilin Agricultural university let the 2012 students to have a test use the test paper of 2011 students about probability theory and mathematical statistics, the test results are shown in the following table.

Table 1. table of student achievement comparison

\begin{tabular}{cccc} 
& the average score & The pass rate & the proportion of more than 90 point \\
\hline Grade 2011 & 65.8 & $80 \%$ & $13 \%$ \\
Grade 2012 & 73.3 & $86 \%$ & $20 \%$
\end{tabular}

We can see from the above data that for the same test papers, the average score, pass rate, and the proportion of more than 90 point of grade 2012 are significantly higher than grade 2011, the effect of grade teaching is obvious.

\section{Summary}

Through detailed research and analysis, we can see that the grade teaching is a mode that teach students in accordance with their aptitude, in order to improve the teaching efficiency as the goal, establish different teaching objectives and plans for different levels students, make best use of the advantages and bypass the disadvantages, is a new teaching model with good prospects. It can tap the potential of every student's own existence and cultivate more high-quality innovative talents. But it also have many problems, we can not follow the same pattern in the specific implementation process, we must continue to explore and improve, carry out reform according to the school's own situation to achieve twice the result with half the effort, give full play to the advantages and strengths of the grade teaching. Learning is endless, we will continue to explore the grade teaching in the future and contribute to the reform of mathematics teaching in China's higher education. 


\section{Acknowledgments}

This work is supported financially by Excellent teaching team project of Jilin Agricultural University. The correspondence author is Jing Wang, wangjing2227@sina.com.

\section{References}

[1] Li Lu, Zhao De-jun. Thinking and exploration on the grade teaching of college mathematics [J]. University Education, 2012(8):100-100.

[2] Zhao De-jun, Li Lu. The present situation and enlightenment of the grading teaching of college mathematics course [J]. University Education, 2013(1):100-102.

[3]Shan Wei, Zhou Qin. Exploration and research on the classification teaching of public basic course of college mathematics [J]. Journal of higher education in science \& technology, 2010, 29(5):95-97.

[4]You Li-xia. Talking about the grading teaching of college mathematics [J]. The science education article collects, 2013(30):67-67.

[5]Ou Chun-xia. A theoretical analysis of and new ideas for graded teaching of advanced mathe matics [J]. Social work and management, 2009, 9(3):35-38.

[6]Zhang Bao-shan. The present situation of college mathematics teaching and the idea of grading teaching platform [J]. College Mathematics, 2007, 23(5):5-7. 